\title{
Determinants of Aortic Cyclic Guanosine Monophosphate in Hypertension Induced by Chronic Inhibition of Nitric Oxide Synthase
}

\author{
Jean-François Arnal, Laurence Warin, and Jean-Baptiste Michel \\ Institut National de la Santé et de la Recherche Médicale (INSERM) Unit 367, 75005 Paris, France
}

\begin{abstract}
Nitric oxide (NO) and atrial natriuretic factor (ANF) cause vascular relaxation by generating cyclic guanosine monophosphate (cGMP) via activation of the soluble and particulate guanylate cyclases, respectively. The chronic effects of $\boldsymbol{N}^{\boldsymbol{G}}$-nitro-L-arginine methyl ester (L-NAME), an L-arginine antagonist and NO synthase inhibitor, on the blood pressure and plasma and aortic cGMP levels of rats were tested. Wistar rats ( $n=10$ per group) were given doses of $L-N A M E(0,1,5,10,20$, 50 , and $100 \mathrm{mg} / \mathrm{kg} \cdot \mathrm{d}$ ) by gavage twice a day for $4 \mathrm{wk}$. Chronic L-NAME induced a time- and dose-dependent increase in blood pressure. The total heart weight/body weight ratio did not change in any group, despite the hypertension. The plasma levels of cGMP did not change significantly in any group, and were correlated with the plasma ANF levels $(r=0.51, P<0.0001)$. Aortic cGMP decreased in negative correlation with increasing L-NAME from 0 to $10 \mathrm{mg} / \mathrm{kg} \cdot \mathrm{d}$, culminating in a 10-fold drop arterial wall cGMP. The aortic cGMP content of rats in the four highest dose groups (from 10 to $100 \mathrm{mg} / \mathrm{d}$ ) tended to increase slightly and was positively correlated with endogenous ANF ( $r=0.48, P<0.002, n=40)$. Intravenous L-arginine decreased arterial blood pressure and reversed the decline in aortic cGMP. Exogenous ANF and sodium nitroprusside both significantly increased aortic cGMP. Neither the arterial wall concentrations of cGMP-dependent kinase nor cAMP was changed by L-NAME. Thus, chronic blockade of NO synthase with L-NAME induces a dose-dependent increase in blood pressure and decrease in aortic cGMP. The in vivo basal aortic cGMP seems to be mainly dependent on NO synthase: soluble guanylate cyclase activity and to a minor extent on particulate guanylate cyclase activity. (J. Clin. Invest. 1992. 90:647-652.) Key words: atrial natriuretic factor - cyclic guanosine monophosphate $\bullet$ hypertension $\cdot$ nitric oxide $\cdot N^{\boldsymbol{G}}$-nitro-L-arginine methyl ester
\end{abstract}

\section{Introduction}

The major role played by the endothelium in modulating the vasomotor response and in structural alterations of the vascu-

Address reprint requests to Dr. Arnal, INSERM Unite 367, 17 rue du Fer-à-Moulin, 75005 Paris, France.

Received for publication 10 February 1992 and in revised form 14 May 1992.

J. Clin. Invest.

(C) The American Society for Clinical Investigation, Inc.

$0021-9738 / 92 / 08 / 0647 / 06 \$ 2.00$

Volume 90, August 1992, 647-652 lar wall has received considerable attention (1-4). Pharmacological studies have shown that endothelial function is influenced differently, depending on the model of chronic hypertension used. Several groups have reported reduced endothelium-dependent vascular responses (5-8), whereas other workers have reported no change (9) or an increase (10) in endothelium-dependent relaxation in arteries from hypertensive animals. Reduced endothelium-dependent vascular relaxation has also been reported in heart failure (11-13) and in the presence of atherosclerotic lesions (14-16). Endotheliumderived relaxing factor (EDRF), ${ }^{1}$ which appears to be nitric oxide (NO), seems to be an ideal modulator of local blood flow, because stimulation of its release integrates both mechanical signals (shear stress) and hormonal signals (acetylcholine, bradykinin, etc.) (1-4). Endothelial cells release EDRF-NO, which activates the soluble guanylate cyclase of vascular smooth muscle, resulting in the generation of cyclic guanosine monophosphate (cGMP) and vascular relaxation (17). Cardiac myocytes release atrial natriuretic factor (ANF), which can also cause cGMP production via the activation of the particulate guanylate cyclase (18-20). The amino acid L-arginine is the precursor for the synthesis of NO by vascular endothelial cells (4). $N^{G}$ monomethyl-L-arginine (L-NMMA), an inhibitor of the NO synthase in vitro, inhibits the release of $\mathrm{NO}$ from endothelial cells and aortic rings, indicating that there is a continuous release of NO, which maintains a dilator tone in this tissue. Short-term administration of L-NMMA induces an increase in blood pressure of $\sim 30 \mathrm{mmHg}$ in rats (21). However, the in vivo effects (in particular on second messengers) of chronic blockade of NO synthase have not yet been reported.

In the present study, rats were given various doses of the orally active L-arginine antagonist $N^{G}$-nitro-L-arginine methyl ester (L-NAME), for a period of 4 wk. This chronic treatment induced a dose-dependent increase in blood pressure. The humoral (plasma and urine) and tissue (aorta and lung) concentrations of cGMP were determined. The concentrations of cyclic adenosine monophosphate (cAMP), the other intracellular second messenger involved in the relaxation of smooth muscle cells, and cGMP-dependent protein kinase within the arterial wall were also measured. The consequences of chronic inhibition of NO generation on the renin-angiotensin system and the plasma ANF were studied. Lastly, the effects of administering L-arginine, exogenous ANF, and sodium nitroprusside (an activator of soluble guanylate cyclase) on blood pressure and aortic cGMP concentration were assessed.

1. Abbreviations used in this paper: ANF, atrial natriuretic factor; EDRF, endothelium-derived relaxing factor; L-NAME, $N^{\mathrm{G}}$-nitro-L-arginine methyl ester; L-NMMA, $N^{\mathrm{G}}$-monomethyl-L-arginine; PRA, plasma renin activity. 


\section{Methods}

Experimental design and animal preparation. Seven groups of 10 normotensive young male Wistar rats (Iffa Credo, Lyon, France) weighing 120-130 g, were studied. The control group were given the solvent (water), the six remaining groups were given doses of L-NAME $(1,5$, $10,20,50$, and $100 \mathrm{mg} / \mathrm{kg} \cdot \mathrm{d}$ ) by gavage, twice a day for $4 \mathrm{wk}$. Systolic blood pressure was measured every $5 \mathrm{~d}$ by the tail-cuff method $\sim 6-8 \mathrm{~h}$ after gavage $(\mathrm{W}+\mathrm{W}$ electronic recorder model 8005 , Apelab, Bagneux, France). At the end of the experimental month, each rat was placed in a metabolic cage and urine was collected for $15 \mathrm{~h}$. Only one rat (given 5 $\mathrm{mg} / \mathrm{d}$ ) died before the end of the study. At the end of the experimental protocol, all the rats were killed by decapitation. Blood samples were collected into prechilled $10-\mathrm{ml}$ tubes containing $2 \mathrm{mg} / \mathrm{ml}$ sodium EDTA, $10 \mu$ l of phenylmethylsulfonyl fluoride in ethanol $(4.25 \mathrm{mg} / \mathrm{ml})$ and $25 \mu \mathrm{l}$ of aprotonin $(200,000$ protease inhibitor units $/ \mathrm{ml})$ from the unanesthetised rats at the time of decapitation. These samples were centrifuged for $10 \mathrm{~min}$ at $3,000 \mathrm{~g}$, and the plasma was removed and frozen at $-70^{\circ} \mathrm{C}$. At the same time, arteries and organs were rapidly excised in the following order: thoracic aorta, abdominal aorta and the lung (within a period of time $<3 \mathrm{~min}$ after decapitation). They were rinsed in cold phosphate-buffered saline, frozen in liquid nitrogen, and stored at $-70^{\circ} \mathrm{C}$. Lastly, the heart was excised and weighed.

Two other groups of rats, given $0(n=18)$ or $100 \mathrm{mg}(n=22)$ $\mathrm{L}-\mathrm{NAME} / \mathrm{kg} \cdot \mathrm{d}$ for $4 \mathrm{wk}$, were used for intraarterial blood pressure measurements. The rats were anesthetized with ether, the right carotid artery was cannulated with a polyethylene catheter (PE-50) and connected to a pressure transducer (Harvard Apparatas Co., Inc., S. Natick, MA) and a recorder (Ankersmit France SA, Villeneuve d'Ascq) for continuous monitoring of blood pressure. The right jugular vein was cannulated with an elastomer catheter for injections and blood samples. The two catheters were led to the back of the neck and exteriorized. Rats were placed in a restraining box, where they were allowed to recover. Their blood pressure were allowed to stabilize for $150 \mathrm{~min}$ before an infusion of saline $(1.2 \mathrm{ml} / \mathrm{h})$ was begun. The experimental protocol was then carried out in unanesthetized conscious animals. After a control period of $1 \mathrm{~h}$, bolus injections $(30$ or $90 \mathrm{mg} / \mathrm{kg}$ ) of L-arginine (Sigma Chemical Co, St. Louis, MO) were given to L-NAME $(n=6)$ and to control $(n=8)$ rats, followed by a $25 \mathrm{mg} / \mathrm{kg} \cdot \min$ infusion for one hour. L-NAME rats $(n=5)$ were given a bolus of $10 \mu \mathrm{g} / \mathrm{kg}$ ANF (1-28 rat, Novabiochem, Läufelfingen, Switzerland), followed by a $3 \mu \mathrm{g} / \mathrm{kg} \cdot \min$ infusion during $5 \mathrm{~min}$. L-NAME rats $(n=5)$ were infused with $10 \mu \mathrm{g} / \mathrm{kg} \cdot \mathrm{min}$ sodium nitroprusside (Sigma Chemical Co.) for 5 min. 6 L-NAME rats and 10 control rats were given saline vehicle alone in similar experimental conditions. At the end of the experimental protocol, rats were killed by cervical dislocation. The thoracic aortae were rapidly excised, rinsed in cold phosphate-buffered saline, frozen in liquid nitrogen, and stored at $-70^{\circ} \mathrm{C}$. 2-ml blood samples were collected from the ANF-infused rats at the time of thoracic aorta excision, for plasma ANF determination.

Preparation of tissue samples. The thoracic aorta was homogenized in $10 \mathrm{vol}$ of $0.1 \mathrm{~N} \mathrm{HCl}$ with an all-glass homogenizer at $4^{\circ} \mathrm{C}$ for determination of cyclic nucleotides. The abdominal aorta was homogenized in $10 \mathrm{vol}$ of buffer ( $20 \mathrm{mM} \mathrm{KPO}_{4}, \mathrm{pH} \mathrm{7.0,2} \mathrm{mM}$ benzamidine) with an all-glass homogenizer at $4^{\circ} \mathrm{C}$ for determination of cGMP kinase. A cortical segment of the lung $(\sim 100 \mathrm{mg})$ was homogenized in $10 \mathrm{vol}$ of $0.1 \mathrm{~N} \mathrm{HCl}$ with an all-glass homogenizer at $4^{\circ} \mathrm{C}$ for determination of cyclic nucleotides. All the homogenates were centrifuged at $15,000 \mathrm{~g}$ for $30 \mathrm{~min}$, and aliquots of the supernatants were stored at $-20^{\circ} \mathrm{C}$ until assayed. One of the aliquots was used to determine the protein concentration by the Bio-Rad/Coomassie Brillant Blue G-250 method, as described by Bio-Rad Laboratories, Richmond, CA. Bovine serum albumin (BSA) was used as the standard.

Determination of CGMP and cAMP concentration. A polyclonal antibody against succinyl cGMP was raised in rabbit. The antigen was prepared by coupling succinyl cGMP to human serum albumin by the method of Steiner et al. (22). The antiserum cross-reactivity with cAMP was $0.02 \%$. The radioligand ${ }^{125}$ I-succinyl-cGMP tyrosine methyl ester was prepared in our laboratory. Stock solutions of the succinyl-cGMP tyrosine methyl ester (Sigma Chemical Co.) were iodinated by the methofd of Hunter and Greenwood using carrier-free ${ }^{125}$ I (Amersham, Bucks, UK). The iodination reaction products were separated on Sephadex G-25 Fine (Pharmacia LKB, Uppsala, Sweden). Standard stock solutions of cGMP $(40 \mu \mathrm{M})$ were prepared in water, and the absorbance of the solution was routinely monitored spectrophotometrically (Uvikon 810P, Kontron Instruments, Milan, Italy). Standard dilutions $(40-2,560 \mathrm{pM})$ were made from the stock solution. The $\mathrm{HCl}$ extract containing cGMP were assayed radioimmunologically according to Cailla et al. (23) as modified by Honma et al. (24) to increase sensitivity by succinylating the cGMP before binding to the antibody.

The plasma was deproteinized by adding ice-cold ethanol to give a final suspension volume of $65 \%$ ethanol. The suspension was centrifuged for $10 \mathrm{~min}$ at $3,000 \mathrm{~g}$, the supernatant was transfered to fresh tubes, and the extract evaporated to dryness under a stream of nitrogen at $60^{\circ} \mathrm{C}$. The dried extracts were dissolved in assay buffer before analysis.

Cyclic AMP was determined with a radioimmunoassay kit (RPA 508, Amersham).

Determination of plasma ANF, plasma renin activity (PRA), and urinary aldosterone. Plasma ANF was extracted on a C18 cartridge, and determined by a nonequilibrium radioimmunoassay using a double-antibody system to separate the free and the bound fractions (25). Peptide tracer was labeled with $\mathrm{I}^{125}$ by the chloramine T method (26). PRA was determined as previously described (27). Urinary aldosterone was measured by the method of Pham and Corvol (28).

Determination of cGMP-dependent kinase concentration. The tissue concentration of cGMP-dependent kinase was determined by an ELISA with affinity-purified rabbit anti-cGMP kinase antibodies, as described previously (29). Pure cGMP kinase and rabbit anti-cGMP kinase antibodies was kindly provided by Dr. F. Hofmann (München, FRG). Microtiter plates were coated with pure cGMP kinase for $16 \mathrm{~h}$ at $4^{\circ} \mathrm{C}$. The coating solution was removed by aspiration, and the residual binding sites were saturated at room temperature with buffer $\mathrm{A}(20$ $\mathrm{mM} \mathrm{KPO}_{4}, \mathrm{pH} 7.5,150 \mathrm{mM} \mathrm{NaCl}, 0.01 \% \mathrm{NaN}_{3}$ ) containing $2 \% \mathrm{BSA}$ at $\mathrm{pH} 7.0$ for $1 \mathrm{~h}$. The plates were washed twice with buffer A containing $0.1 \%$ BSA. The affinity-purified rabbit antibodies were preincubated for with three dilutions of tissue extracts or pure cGMP kinase for $16 \mathrm{~h}$ at $4^{\circ} \mathrm{C}$. These probes were transferred to the plates and incubated for $2 \mathrm{~h}$ at $4^{\circ} \mathrm{C}$. The plates were then washed two times. A goat anti-rabbit IgG-peroxidase conjugate was added and the plates were incubated for $1 \mathrm{~h}$ at room temperature. They were washed three times and substrate solution $\left(0.4 \mathrm{mg} / \mathrm{ml} 1,2\right.$ phenylene diamine and $0.001 \% \mathrm{H}_{2} \mathrm{O}_{2}$ in a phosphate-citrate buffer, $\mathrm{pH}$ 5.0) was added. The reaction was stopped after 15 min with $2 \mathrm{~N} \mathrm{HCl}$ and the reaction product was measured at $492 \mathrm{~nm}$. The cGMP kinase concentration was calculated as described in Ecker et al. (29).

Statistical methods. Results are expressed as means \pm 1 SD. The differences in blood pressure and body weight were evaluated by ANOVA with repeated measures (comparison of the seven groups). The difference in the other parameters was evaluated by one factor ANOVA of the increase or decrease of each variable measured (comparison of the groups). One-way analysis of variance followed by Scheffe $F$-test or Fisher PLSD was used to compare the effects of L-NAME doses on these parameters. Linear regression curves and correlation coefficients were obtained by the least-squares method.

\section{Results}

Blood pressure, body weight, and heart weight. Chronic oral administration of L-NAME induced a time and dose-dependent increase in blood pressure in these young rats (Fig 1). Doses of L-NAME over $10 \mathrm{mg} / \mathrm{kg} \cdot \mathrm{d}$ delayed the increase in body weight. However, this smaller weight gain averaged $20 \mathrm{~g}$ for the three highest doses, only $8 \%$ of the body weight of these hypertensive rats versus their normotensive controls (Table I). 


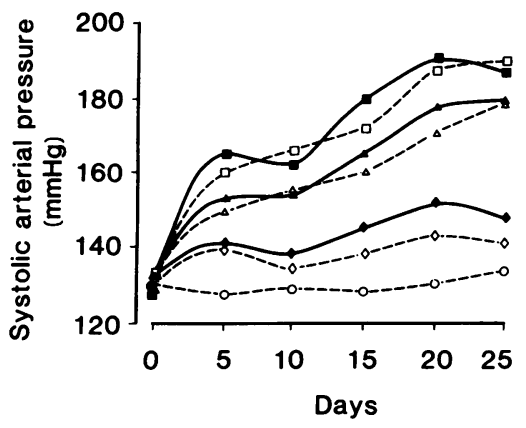

Figure 1. Time- and dose-dependent increase in blood pressure induced by chronic oral administration of $\mathrm{L}-$ NAME in Wistar rats $(n$ $=10$ per group). (o) 0 , $(\diamond) 1,(\diamond) 5,(\Delta) 10,(\Delta)$ 20 , (ㅁ) $50,(\square) 100 \mathrm{mg}$ of L-NAME per $\mathrm{kg} / \mathrm{d}$.

The total heart weight/body weight ratio did not change in any group, despite the dose-dependent increase in blood pressure (Table I). The absolute heart weight was indeed significantly lower in L-NAME treated rats than in control rats $(F 3.87, P$ $<0.003$ ) (Table I).

Blood pressure was measured by the tail-cuff method and intraarterially in the extra group $(n=22)$ given $100 \mathrm{mg} \mathrm{L}-$ $\mathrm{NAME} / \mathrm{kg} \cdot \mathrm{d}$. Systolic blood pressure averaged $192 \pm 17$ $\mathrm{mmHg}$ by the tail-cuff method and $200 \pm 20 \mathrm{mmHg}$ when measured intraarterially.

Plasma and urinary variables (Table II). The plasma cGMP concentration did not change in any group; neither did the 24-h excretion of urinary cGMP. The plasma ANF was slightly increased by L-NAME: the plasma levels of ANF tended to increase in the two groups given the highest dose of L-NAME (50 and $100 \mathrm{mg} / \mathrm{kg} \cdot \mathrm{d}$ ) versus a lower dose of $\mathrm{L}$ NAME $(20 \mathrm{mg} / \mathrm{d})$ (significant only when using Fisher PLSD comparison). The plasma ANF concentration was correlated with the plasma cGMP $(r=0.51, P<0.0001)$. L-NAME slightly decreased the PRA versus control, independently of the dose $(P<0.05)$. 24-h urinary excretion of aldosterone did not change in any group.

Tissue parameters. The cGMP content of the arterial wall was dramatically altered in L-NAME-treated rats $(F 32.45, P$ $<0.0001$ ) (Table II). There was a negative correlation between systolic blood pressure and aortic cGMP $(r=0.67, P<0.0001)$ (Fig. 2). From 0 to $10 \mathrm{mg} \mathrm{L-NAME} / \mathrm{kg} \cdot \mathrm{d}$, there was a dose-dependent decrease (of one order of magnitude) in aortic cGMP; whereas from 20 to $100 \mathrm{mg} / \mathrm{kg} \cdot \mathrm{d}$, there was a tendancy for the aortic cGMP content to increase. The relationship between aortic cGMP content and plasma ANF levels within these groups showed a highly significant positive correlation ( $r$ $=0.48, F 11.41, P<0.002)$ within the four subgroups $(10,20$, 50 , and $100 \mathrm{mg} / \mathrm{kg} \cdot \mathrm{d}$ ), which corresponded to the rats in which NO synthase can be assumed to be blocked by L-NAME (Fig. $3)$. There was a similar correlation between aortic cGMP and plasma ANF in the rats given 20,50 , and $100 \mathrm{mg} / \mathrm{d}(r=0.50, F$ 9.34, $P<0.005)$, and between rats given 50 or $100 \mathrm{mg} /$ ay $(r$ $=0.51, F 6.37, P<0.03)$. However, the rats given $5 \mathrm{mg} \mathrm{L}$ NAME per day or less (in which NO synthase was not completely blocked) showed no correlation between aortic cGMP content and plasma ANF, but cGMP was dependent on the dose of L-NAME $(F 32.45, P<0.0001)$. The pulmonary cGMP content was also influenced by L-NAME (Table II). Doses of 0-5 $\mathrm{mg}$ /day produced a dose-dependent decrease in pulmonary cGMP. The subgroups given $5-100 \mathrm{mg} /$ day had pulmonary cGMP contents that were positively correlated with plasma ANF ( $r=0.40, P<0.005, n=49$ ). Lastly, plasma cGMP levels were correlated with the pulmonary cGMP content $(r=0.45, P<0.0001, n=69)$, but not with aortic cGMP $(r$ $=0.23, \mathrm{NS}, n=69)$.

The arterial cGMP-dependent kinase concentration was not changed by L-NAME. It was $82 \pm 10 \mathrm{ng} / \mathrm{mg}$ protein in rats given $50 \mathrm{mg} / \mathrm{kg} \cdot \mathrm{d} \mathrm{L}-\mathrm{NAME}(n=10)$ and $79 \pm 11 \mathrm{ng} / \mathrm{mg}$ protein in controls $(n=10)$. The cAMP concentration within the arterial wall remained unchanged in all the groups. The values were between $25 \pm 5$ and $29 \pm 7 \mathrm{pmol} / \mathrm{mg}$ protein.

Effects of intravenous L-arginine, ANF, and sodium nitroprusside (Fig. 4). The blood pressure of L-NAME rats given only vehicle, did not change throughout the period of $10 \mathrm{~h}$. Intravenous boluses of 30 and $90 \mathrm{mg} / \mathrm{kg}$ L-arginine to L-NAME rats transiently decreased blood pressure by 20 and $30 \mathrm{mmHg}$, respectively, but the blood pressure returned to baseline within minutes. Infusion of $25 \mathrm{mg} / \mathrm{kg} \cdot \min \mathrm{L}$-arginine for $60 \mathrm{~min}$ decreased blood pressure by $24 \%$. ANF ( $10 \mu \mathrm{g} / \mathrm{kg}$ bolus followed by a $3 \mu \mathrm{g} / \mathrm{kg} \cdot \mathrm{min}$ infusion for $5 \mathrm{~min}$ ) decreased blood pressure by $18 \%$. Infusion of sodium nitroprusside $(10 \mu \mathrm{g} / \mathrm{kg} \cdot \mathrm{min}$ for 5 min) decreased blood pressure by $48 \%$.

L-NAME rats given only saline vehicle had low aortic cGMP (223 $\pm 60 \mathrm{fmol} / \mathrm{mg}$ protein, $n=6)$. L-arginine reversed the decline in aortic cGMP $(1,984 \pm 473 \mathrm{fmol} / \mathrm{mg}$ protein, $n$ $=6)$. Exogenous ANF and sodium nitroprusside also increased the aortic cGMP concentration $(4,470 \pm 1,702 \mathrm{fmol} / \mathrm{mg}$ protein, $n=5$ and $7,531 \pm 3,083 \mathrm{fmol} / \mathrm{mg}$ protein, $n=5$, respectively). The plasma ANF concentration was increased

Table I. Systolic Blood Pressure, Body Weight, Heart Weight, Total Heart Weight/Body Weight Ratio at the End of 4 wk of Treatment

\begin{tabular}{|c|c|c|c|c|}
\hline & Systolic blood pressure D25 & Weight D28 & Heart weight & Heart weight index \\
\hline & $m m H g$ & $g$ & $m g$ & $m g / g$ \\
\hline Control $(n=10)$ & $133 \pm 8$ & $264 \pm 16$ & $771 \pm 52$ & $2.92 \pm 0.14$ \\
\hline L-NAME $1 \mathrm{mg} / \mathrm{kg}(n=10)$ & $141 \pm 10$ & $257 \pm 16$ & $717 \pm 54$ & $2.78 \pm 0.18$ \\
\hline L-NAME $5 \mathrm{mg} / \mathrm{kg}(n=9)$ & $148 \pm 10$ & $263 \pm 22$ & $710 \pm 55$ & $2.71 \pm 0.24$ \\
\hline L-NAME $10 \mathrm{mg} / \mathrm{kg}(n=10)$ & $181 \pm 18$ & $266 \pm 14$ & $742 \pm 53$ & $2.79 \pm 0.14$ \\
\hline L-NAME $20 \mathrm{mg} / \mathrm{kg}(n=10)$ & $180 \pm 14$ & $235 \pm 22$ & $655 \pm 58^{*}$ & $2.79 \pm 0.16$ \\
\hline L-NAME $50 \mathrm{mg} / \mathrm{kg}(n=10)$ & $190 \pm 11$ & $244 \pm 14$ & $707 \pm 63$ & $2.89 \pm 0.26$ \\
\hline L-NAME $100 \mathrm{mg} / \mathrm{kg}(n=10)$ & $187 \pm 17$ & $246 \pm 21$ & $720 \pm 65$ & $2.92 \pm 0.15$ \\
\hline$P$ value & $<0.0001$ & $<0.001$ & $<0.003$ & NS \\
\hline
\end{tabular}

* Scheffe $F$-test: $3.46, P<0.05$, control vs. L-NAME $20 \mathrm{mg} / \mathrm{kg}$. 


\begin{tabular}{|c|c|c|c|c|c|c|c|}
\hline & PRA & $\begin{array}{c}\text { Excretion of } \\
\text { urinary aldosterone }\end{array}$ & ANF & Plasma cGMP & $\begin{array}{l}\text { Excretion of } \\
\text { urinary CGMP }\end{array}$ & $\begin{array}{l}\text { Aortic cGMP } \\
\text { content }\end{array}$ & $\begin{array}{l}\text { Pulmonary cGMP } \\
\text { content }\end{array}$ \\
\hline & $n g A I / m l \cdot h$ & $\mu g / 24 h$ & $p g / m l$ & $\mathrm{pmol} / \mathrm{ml}$ & $n \mathrm{~mol} / 24 \mathrm{~h}$ & \multicolumn{2}{|c|}{ pmol/mg protein } \\
\hline Control $(n=10)$ & $4.82 \pm 1.75$ & $2.30 \pm 0.54$ & $259 \pm 122$ & $7.5 \pm 1.9$ & $18 \pm 2$ & $2,433 \pm 1094$ & $271 \pm 112$ \\
\hline L-NAME $1 \mathrm{mg} / \mathrm{kg}(n=10)$ & $3.35 \pm 0.87$ & $2.09 \pm 0.93$ & $286 \pm 81$ & $7.5 \pm 2.5$ & $21 \pm 2$ & $1,151 \pm 376$ & $195 \pm 68$ \\
\hline L-NAME $5 \mathrm{mg} / \mathrm{kg}(n=9)$ & $3.42 \pm 1.40$ & $1.66 \pm 0.50$ & $259 \pm 81$ & $6.6 \pm 1.9$ & $25 \pm 3$ & $452 \pm 129$ & $119 \pm 37$ \\
\hline L-NAME $10 \mathrm{mg} / \mathrm{kg}(n=10)$ & $2.82 \pm 1.23$ & $2.17 \pm 0.53$ & $258 \pm 67$ & $7.7 \pm 4.2$ & $22 \pm 2$ & $270 \pm 52$ & $150 \pm 24$ \\
\hline L-NAME $20 \mathrm{mg} / \mathrm{kg}(n=10)$ & $2.91 \pm 2.18$ & $1.94 \pm 0.75$ & $174 \pm 61$ & $5.7 \pm 1.4$ & $18 \pm 2$ & $258 \pm 71$ & $120 \pm 31$ \\
\hline L-NAME $50 \mathrm{mg} / \mathrm{kg}(n=10)$ & $2.91 \pm 0.72$ & $1.73 \pm 0.69$ & $344 \pm 148$ & $7.3 \pm 3.6$ & $22 \pm 2$ & $301 \pm 104$ & $128 \pm 68$ \\
\hline L-NAME $100 \mathrm{mg} / \mathrm{kg}(n=10)$ & $3.72 \pm 1.13$ & $1.83 \pm 0.37$ & $343 \pm 173$ & $6.0 \pm 1.2$ & $20 \pm 2$ & $313 \pm 69$ & $95 \pm 31$ \\
\hline$P$ value & $<0.05$ & NS & $<0.05$ & NS & NS & $<0.0001$ & $<0.0001$ \\
\hline
\end{tabular}

Abbreviation: AI, angiotensin $\mathrm{I}$.

$(32,072 \pm 12,829 \mathrm{pg} / \mathrm{ml}$, i.e., about 100 times the control) by the infusion of exogenous ANF.

In control normotensive rats, intravenous boluses of 90 $\mathrm{mg} / \mathrm{kg}$ L-arginine decreased blood pressure by $10 \mathrm{mmHg}$, but the blood pressure returned to baseline within seconds. Infusion of $25 \mathrm{mg} / \mathrm{kg} \cdot \min \mathrm{L}$-arginine for $60 \mathrm{~min}$ did not change blood pressure. Control rats given only saline vehicle had unchanged aortic cGMP $(1,925 \pm 938 \mathrm{fmol} / \mathrm{mg}$ protein, $n=10)$. L-arginine did not change aortic cGMP concentration $(2,252 \pm 920 \mathrm{fmol} / \mathrm{mg}$ protein, $n=8)$ in these normotensive rats.

\section{Discussion}

Chronic oral administration of L-NAME induces a dose-dependent increase in blood pressure and can be considered to be a novel model of experimental hypertension. The body weight gain in these immature rats was slightly but significantly slowed by a L-NAME. Some decrease in body weight gain is a common feature of all models of hypertension. Surprisingly, this increase in blood pressure was not associated with any degree of cardiac hypertrophy. The heart weight/body weight ratio was quite similar to that of the controls. To our knowledge, this is the first time that chronic experimental hypertension has not induced cardiac hypertrophy. For instance, at $1 \mathrm{mo}$, renovascular rats show massive cardiac hypertrophy (30). This discrepancy between high blood pressure and the absence of cardiac hypertrophy in this model requires further investigation.

Endothelial cells release EDRF-NO, which activates vascular smooth muscle soluble guanylate cyclase, resulting in cGMP generation and vascular relaxation (1-4). The present study demonstrates that rats chronically treated with L-NAME exhibit a dose-dependent decrease in arterial wall cGMP, culminating in a 10 -fold drop in the arterial wall cGMP content at a dose $\geq 10 \mathrm{mg} / \mathrm{kg} \cdot$ day L-NAME. Intravenous L-arginine partially restores the hypertension and reverses the decline in aortic cGMP. The cGMP content of the arterial wall therefore appears to be a very sensitive index of in vivo NO synthase activation. Endogenous ANF was positively correlated with the cGMP content of the arterial wall in rats given the highest doses of L-NAME $(20-100 \mathrm{mg} / \mathrm{kg} \cdot$ day $)$. A twofold increase in endogenous ANF was associated with a twofold increase in aortic cGMP, which remained sixfold lower than that of the control normotensive rats. Thus, the contribution of endogenous ANF, via stimulation of the particulate guanylate cyclase, to basal aortic cGMP generation appears to be minor compared to that of EDRF-NO via soluble guanylate cyclase. However, pharmacological doses of exogenous ANF or sodium nitroprusside produced large increases in aortic cGMP in L-NAME, attesting to the integrity of the particulate and soluble guanylate cyclases. Finally, at least two phosphodiesterases catabolise cGMP, and thus influence smooth muscle cGMP concentration (31). It is always possible that the phosphodiesterases may be both induced and inhibited, as a reaction to the new steady state level.

The presence of cGMP in extracellular fluids is believed to be the consequence of its egress through the cell membrane. This membrane is impermeable to its reentry unless the molecules are modified, rendering them lipophilic, as is 8-bromocGMP (20). ANF activates the particulate guanylate cyclase in both cultured endothelial cells and vascular smooth muscle cells leading to increased intra- and extracellular cGMP (20). $\mathrm{NO}$, as sodium nitroprusside, activates the soluble guanylate cyclase of vascular smooth muscle, and also leads to increased intra- and extracellular cGMP (17-19). The cellular heterogeneity of the organs makes it difficult to assess the in vivo status of the second messengers. However, large vessels, such as the aorta, contain mainly matrix and smooth muscle cells; the endothelium is limited to a very thin monolayer. Conversely, the lung is particularly rich in capillaries, and hence in endothelial cells. Thus, we may assume that the aortic cGMP levels reflect the cGMP concentration in smooth muscle cells, while the lung cGMP levels mainly reflect the cGMP concentration in

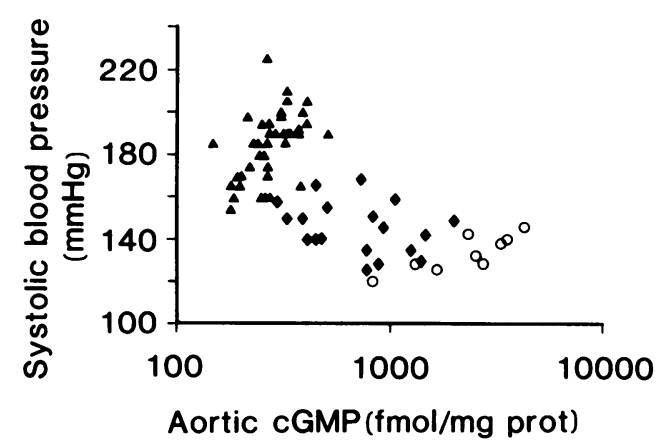

Figure 2. Relationship between systolic blood pressure and aortic cGMP. (০) Control rats; (४) 1-5 mg of L-NAME per kg/d; ( $\triangle$ ) 10-100 mg of L-NAME per kg/d $(r=0.67, P<0.0001, n=69)$. 
both endothelium and smooth muscle cells. Indeed, L-NAME induced a 10-fold decrease in aortic cGMP and only a two- to threefold decrease in pulmonary cGMP. But neither plasma nor urinary cGMP levels were altered in the present study, despite a large decrease in its concentrations within the arterial wall, i.e., smooth muscle cells. Humoral cGMP does not reflect the aortic cGMP level or the activity of soluble guanylate cyclase. The correlation between plasma ANF, plasma cGMP, and pulmonary cGMP suggests that plasma cGMP originates from stimulation of the endothelial particulate guanylate cyclase by ANF, which is in agreement with a clinical study (32).

Cyclic GMP-dependent kinase appears to mediate the effects of cGMP, and perhaps also of cAMP, in smooth muscle cells (33). In aortic rings exposed to antagonists of the L-arginine/NO pathway, decreased basal tissue cGMP may enhance the sensitivity to any exogenous vasodilator during exposure to antagonists of the L-arginine/NO pathway (34). This change could be due to induction of cGMP-dependent kinase. However, our results do not demonstrate any change in the arterial concentration of cGMP-dependent kinase in response to LNAME. The dramatic decrease in arterial cGMP does not appear to influence the level of cAMP, the other cyclic nucleotide implicated in the relaxation of the vascular tone.

An increase in renal perfusion pressure is known to decrease renin secretion (35). However, recent studies have suggested that the endothelium, and potentially NO, can stimulate renin secretion. Our group has recently demonstrated that renin secretion is inhibited by L-NAME in isolated kidneys perfused at constant pressure (36). Renin secretion is also inhibited by L-NMMA in cocultures of endothelial cells and juxtaglomerular cells (37). Blood pressure increased dose-dependently during chronic administration of L-NAME, whereas the plasma renin secretion was slightly inhibited at the smallest dose and then plateaued. The present study suggests that the in vivo control of renin secretion during chronic L-NAME administration is influenced by factors other than NO blockade and high blood pressure, and that these factors counterregulate in vivo secretion.

In conclusion, the present study emphasizes the importance of NO and its second messenger CGMP in the regulation of blood pressure. Chronic administration of L-NAME induces a time- and dose-dependent increase in blood pressure and decreased aortic cGMP by 10 -fold. The present data indicate

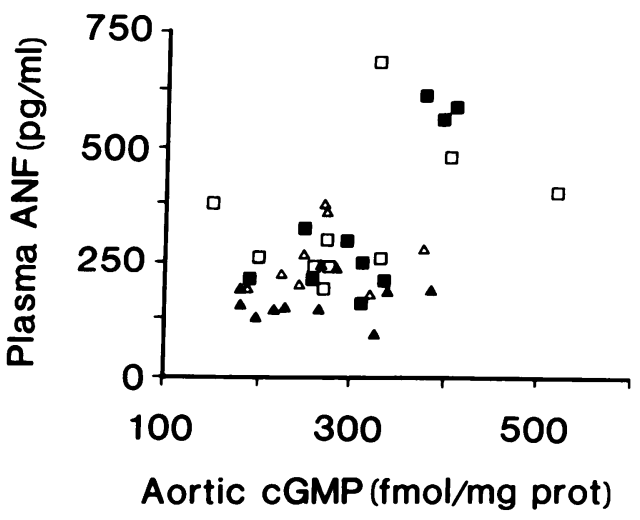

Figure 3. Relationship between aortic cGMP and plasma ANF levels in the rats given the four highest L-NAME doses: $(\Delta) 10,(\Delta) 20$, ( $\square$ ) 50 , (口) $100 \mathrm{mg} / \mathrm{kg} \cdot \mathrm{d}(r=0.48, P<0.002, n=40)$.

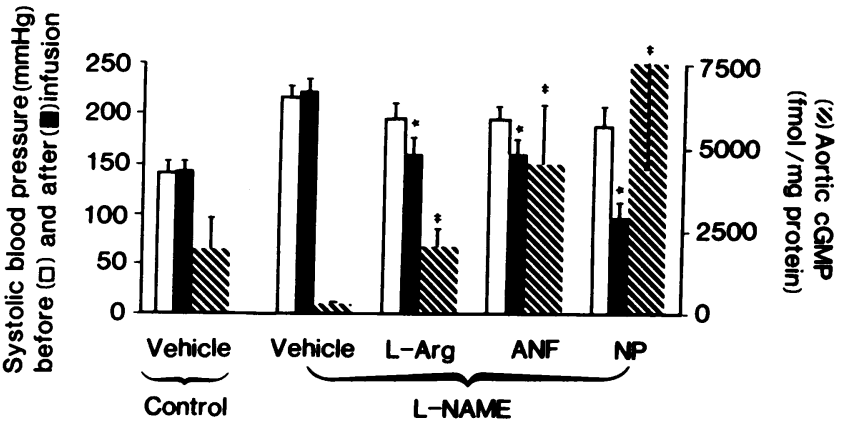

Figure 4. Effect of intravenous L-arginine ( $L-A r g)$, ANF, and sodium nitroprusside $(N P)$ in L-NAME $(100 \mathrm{mg} / \mathrm{kg} \cdot \mathrm{d})$ rats. Systolic blood pressure $(\mathrm{mmHg})$ before ( $(\square)$ versus after $(\square)$ the infusion: ${ }^{*} P<0.05$. Aortic cGMP (fmol/mg protein, ( $($ ) $): P<0.05$ vs. vehicle L-NAME rats.

that the in vivo basal level of arterial cGMP mainly depends on soluble guanylate cyclase activity. However, pharmacological doses of exogenous ANF or sodium nitroprusside both considerably increased aortic cGMP in this model of chronic administration of NO synthase antagonist. Humoral (plasma and urinary) cGMP does not reflect the arterial status of arterial wall cGMP. The plasma cGMP seems to be dependent on the endothelial particulate guanylate cyclase activity, as suggested by the correlation between the plasma and the pulmonary cGMP content. The direct measurement of arterial cGMP provides an additional approach to the in vivo study of NO synthase/soluble guanylate cyclase pathway activity within the arterial wall.

\section{Acknowledgments}

We thank Annie Depardieu for the artwork and Drs. François AlhencGelas, Joël Ménard, François-Xavier Galen, and Barry Greenberg for fruitful discussions.

This work was supported in part by the Institut National de la Santé et de la Recherche Médicale and by the Assistance Publique des Hôpitaux de Paris.

\section{References}

1. Furchgott, R. F., and P. M. Vanhoutte. 1989. Endothelium-derived relaxing and contracting factors. FASEB (Fed. Am. Soc. Exp. Biol.) J. 3:2007-2018.

2. Rapoport, R. M., and F. Murad. 1988. Role of cyclic GMP in endotheliumderived relaxation of vascular smooth muscle. In Relaxing and Contracting Factors. P. M. Vanhoutte, editor. Humana Press, Clifton, NJ. 219-239.

3. Ignarro, L. J. 1989. Biological actions and properties of endothelium-derived nitric oxide formed and released from artery and vein. Circ. Res. 65:1-21.

4. Moncada, S., R. M. J. Palmer, and E. A. Higgs. 1991. Nitric oxide: physiology, pathophysiology, and pharmacology. Pharmacol. Rev. 43:109-142.

5. Winquist, R. J., P. B. Bunting, E. P. Baskin, and A. A. Wallace. 1984. Decreased endothelium-dependent relaxation in New Zealand genetic hypertensive rats. J. Hypertens. 2:541-545.

6. De Mey, J. G., and S. D. Gray. 1985. Endothelium-dependent reactivity in resistance vessels. Prog. Appl. Microcirc. 8:181-187.

7. Lüscher, T. F., L. Raij, and P. M. Vanhoutte. 1987. Effect of hypertension and its reversal on endothelium-dependent relaxations in the rat aorta. J. Hypertens. 5:S153-S155.

8. Otsuka, U., A. Dipiero, E. Hirt, B. Brennaman, and W. Lockette. 1988. Vascular relaxation and CGMP in hypertension. Am. J. Physiol. 254:H163H169.

9. Hagen, G. C., and R. C. Webb. 1984. Coronary artery reactivity in deoxycorticosterone acetate hypertensive rats. Am. J. Physiol. 247:H409-H414.

10. Konishi, M., and C. Su. 1983. Role of endothelium in dilator responses of spontaneously hypertensine rat arteries. Hypertension. 5:881-886.

11. Kaiser, L., R. C. Spickard, and N. B. Olivier. 1989. Heart failure depresses 
endothelium-dependent responses in canine femoral artery. Am. J. Physiol. 256:H962-H967.

12. Ontkean, M., R. Gay, and B. Greenberg. 1991. Diminished endotheliumderived relaxing factor activity in an experimental model of chronic heart failure. Circ. Res. 69:1088-1096.

13. Kubo, S. H., T. S. Rector, A. J. Bank, R. E. Williams, and S. M. Heifetz. 1991. Endothelium-dependent vasodilation is attenuated in patients with heart failure. Circulation 84:1589-1596.

14. Verbeuren, T. J., F. H. Jordaens, L. L. Zonnekeyn, C. E. Van Hove, M. C. Coene, and A. G. Herman. 1986. Effect of hypercholesterolemia on vascular reactivity in the rabbit. Circ. Res. 58:552-564.

15. Creager, M. A., J. P. Cooke, M. E. Mendelsohn, S. J. Gallagher, S. M Coleman, J. Loscalzo, and V. J. Dzau. 1990. Impaired vasodilation of forearm resistance vessels in hypercholesterolemic humans. J. Clin. Invest. 86:228-234.

16. Chester, A. H., G. S. O'Neil, S. Moncada, S. Tadjkarimi, and M. H. Yacoub. 1990. Low basal and stimulated release of nitric oxide in atherosclerotic epicardial coronary artenes. Lancet. 336:897-900.

17. Katsuki S., W. Arnold, C. Mittal, and F. Murad. 1977. Stimulation of guanylate-cyclase by sodium nitroprusside, nitroglycerin and nitric oxide in various tissue preparations and comparison to the effects of sodium azide and hydroxylamine. J. Cyclic. Nucleotide Res. 3:23-35.

18. Waldman, S. A., R. M. Rapoport, and F. Murad. 1984. Atrial natriuretic factor selectively activates particulate guanylate cyclase and elevates cyclic GMP in rat tissues. J. Biol. Chem. 259:14332-14334.

19. Schini, V., P. Schoeffter, and R. C. Miller. 1989. Effect of endothelium on basal and on stimulated accumulation and efflux of cyclic GMP in rat isolated aorta. Br. J. Pharmacol. 97:853-865.

20. Hamet, P., S. C. Pang, and J. Trembley. 1989. Atrial natriuretic factor-induced egression of cyclic guanosine $3^{\prime}: 5^{\prime}$-monophosphate in cultured vascular smooth muscle and endothelial cells. J. Biol. Chem. 264:12364-12369.

21. Gardiner, S. M., A. M. Compton, T. Bennett, R. M. J. Palmer, and S. Moncada. 1990. Persistent heamodynamic changes following prolonged infusions of $\mathrm{N}^{\mathrm{G}}$-monomethyl-L-arginine methyl ester in concious rats. In Nitric Oxide from L-Arginine: a Bioregulatory System. S. Moncada and E. A. Higgs, editors Elsevier, Amsterdam. 489-491.

22. Steiner, A. L., C. W. Parker, and D. M. Kipnis. 1972. Radioimmunoassay for cyclic nucleotides. I. Preparation of antibodies and iodinated cyclic nucleatides. J. Biol. Chem. 247:1106-1113.

23. Cailla, H. L., C. T. Vannier, and M. A. Delaage. 1976. Guanosine 3',5'cyclic monophosphate assay at 10 ${ }^{-15}$ mole level. Anal. Biochem. 70:195-202.

24. Honma, M., T. Satoh, J. Takezawa, and M. Ui. 1977. An ultrasensitive method for the simultaneous determination of cyclic AMP and cyclic GMP in small-volume samples from blood and tissue. Biochem. Med. 18:257-273.

25. Bouissou, P., F. X. Galen, J. P. Richalet, M. Lartigue, F. Devaux, C. Dubray, and G. Atlan. 1989. Effects of propranolol and pindolol on plasma ANP levels in humans at rest and during exercise. Am. J. Physiol. 257:R259-R264.

26. Greenwood, F. C., W. M. Hunter, and J. G. Glover. 1963. The preparation of ${ }^{131}$ I labeled human growth hormones of high specific radioactivity. Biochem. J. 89:114-118.

27. Ménard, J. M., and K. J. Catt. 1972. Measurement of renin activity, concentration and substrate in rat plasma by radioimmunoassay of angiotensin $\mathrm{I}$. Endocrinology. 90:422-430.

28. Pham Huu Trung, M. T., and P. Corvol. 1974. A direct determination of plasma aldosterone. Steroids. 24:587-598.

29. Ecker, T., C. Göbel, R. Hullin, R. Rettig, G. Seitz, and F. Hofmann. 1989. Decreased cardiac concentration of CGMP kinase in hypertensive animals: an index for cardiac vascularisation? Circ. Res. 65:1361-1369.

30. Dussaule, J. C., J. B. Michel, C. Auzan, K. Schwartz, P. Corvol, and J. Menard. 1986. Effect of antihypertensive treatment on the left ventricular isomyosin profile in one-clip, two kidney hypertensive rats. J. Pharmacol. Exp. Ther. 236:512-518.

31. Lugnier, C., P. Schoeffter, A. Le Bec, E. Strouthou, and J. C. Stoclet. 1986. Selective inhibition of cyclic nucleotide phosphodiesterases of human, bovine and rat aorta. Biochem. Pharmacol. 35:1743-1751.

32. Roy, L. R. R. I. Ogilvie, P. Larochelle, P. Hamet, and F. Leenen. 1989. Cardiac and vascular effects of atrial natriuretic factor and sodium nitroprusside in healthy men. Circulation. 79:383-392.

33. Lincoln, T. M., T. L. Cornwell, A. E. Taylor. 1990. CGMP-dependent protein kinase mediates the reduction of $\mathrm{Ca}^{2+}$ by cAMP in vascular smooth muscle cells. Am. J. Physiol. 278:C399-C407.

34. Moncada, S., D. D. Rees, R. Schulz, and R. M. J. Palmer. 1991. Development and mechanism of a specific supersensitivity to nitrovasodilators following inhibition of vascular nitric oxide synthesis in vivo. Proc. Natl. Acad. Sci. USA. 88:2166-2170.

35. Kirchheim, H., H. Ehmke, and P. Persson. 1990. Role of blood pressure in the control of renin release. Acta Physiol. Scand. 139(Suppl. 591):40-47.

36. Gardes, J., J. M. Poux, M. F. Gonzalez, F. Alhenc-Gelas, and J. Ménard. 1992. Decreased renin release and constant kallikrein secretion after injection of L-NAME in isolated perfused rat kidney. Life Sci. 50:987-993.

37. Kurtz, A., B. Kaissling, R. Busse, and W. Baier. 1991. Endothelial cells modulate renin secretion from isolated mouse juxtaglomerular cells. J. Clin. Invest. 88:1147-1154. 